\title{
Re-use of Agaricus bisporus Spent Compost for Commercial Scale Compost Making of the Succeeding Crop of A. bisporus
}

\author{
Om Parkash Ahlawat ${ }^{1,2} *$ and Harleen Kaur ${ }^{1}$ \\ ${ }^{1}$ ICAR-Directorate of Mushroom Research, Solan 173213 (HP), India \\ ${ }^{2}$ ICAR-Indian Institute of Wheat and Barley Research, Karnal 132 001, Haryana, India \\ *Corresponding author
}

\begin{tabular}{|l|}
\hline Key w or d s \\
$\begin{array}{l}\text { Spent mushroom } \\
\text { substrate, Agaricus } \\
\text { bisporus, Compost } \\
\text { output, Fruit body } \\
\text { yield, Nutritional } \\
\text { quality }\end{array}$ \\
\hline Article Info \\
\hline $\begin{array}{l}\text { Accepted: } \\
\text { 04 October } 2019 \\
\text { Available Online: } \\
\text { 10 November } 2019\end{array}$ \\
\hline
\end{tabular}

A B S T R A C T
White button mushroom (Agaricus bisporus) is cultivated on a well decomposed substrate, and the left over substrate after crop harvest known as 'spent mushroom substrate or compost' (SMS) is not finding many uses. The present study proves that the use of SMS in partial replacement of wheat straw in compost making for A. bisporus cultivation gives higher compost output/unit wt. of wheat straw with superior nutritional profile and higher fruit body yield along with superior nutritional composition. The button mushroom compost was prepared by using fresh SMS of button mushroom in three different proportions along with wheat straw, keeping standard wheat straw based formulation as control in two phase short method of composting. The compost output/unit wt. of wheat straw was 3.54 to 4.35 folds in SMS added treatments compared to 3.04 folds in standard formulation. The composts prepared with addition of SMS were superior in total nitrogen, cellulose, lignin, potassium and phosphorus along with lower $\mathrm{C} / \mathrm{N}$ ratio (17: 1) compared to control (20: 1). The SMS amended composts gave fruit body yield either higher or at par with control along with higher contents of total ash, vitamin $\mathrm{D}$ and minerals on dry wt. basis in harvested fruit bodies.

\section{Introduction}

Agaricus bisporus (button mushroom) is the most extensively grown mushroom worldwide, shares around $30 \%$ of the total world mushroom production (Royse, 2014). It also accounts for around $85 \%$ of India's total mushroom production (Singh, 2011). This mushroom is grown on a composted substrate prepared from the mixtures of different agroresidues like hay, corncobs, wheat straw, horse and poultry manures, cottonseed hulls, corn stover, gypsum, etc. (Van Griensven, 1988). The agro-residues used for compost making vary from region to region and farm to farm. The preparation of quality compost for A. bisporus accounts for up to $50 \%$ of the cost of mushroom production (Wuest, 1983; Van 
Roestel, 1988). The left over substrate after harvesting of one full crop of mushrooms is called as spent mushroom substrate (SMS). The term "spent mushroom compost" (SMC) is used interchangeably with "spent mushroom substrate" (SMS) describing the agro-residues and fungal mycelium left after harvesting of mushrooms (Phan and Sabaratnam, 2012). Further, the ratio between the fresh mushrooms to the generation of SMS in different mushrooms is 1:3 to 1:5 (Williams et al., 2001). So going by the figure of 27 million tonnes of total world mushroom production per annum in 2012 (Royse, 2014), around 81 to 135 million tonnes of SMS is produced annually. Handling of such a huge quantity of material is a cumbersome task as along with occupying the large space, it causes several environmental problems if not handled properly (Beyer, 1996). Hence, the disposal of SMS merits renewed emphasis in the wake of alarming damages to the environment and ecosystem.

SMS from $A$. bisporus is rich in nitrogen $(2.7 \%)$ and organic matter $(61 \%)$ and it also involves varying disposal cost to the mushroom growers (Royse, 2012; Fidanza and Beyer, 2009). There are several reports on its re-utilization for cultivating mushrooms like A. bisporus (Royse, 2012), Lentinula sp. (Kilpatrick, 2000), Pleurotus sp. (Mueller, 1984), and Volvariella sp. (Poppe, 2000). The use of A. bisporus spent substrate as basal ingredient especially for compost making to grow A. bisporus, offers several benefits like: (1) significantly reduces the volume of compost ingredients needed - a substantial economic benefit as wheat straw is becoming more costly day by day due to its primary use as animal fodder, (2) reduces the volume of spent mushroom compost left to find beneficial reuse, and (3) improves quality of spent mushroom compost as double cropped compost may be usable with less processing as a manure. As evident from above stated benefits of using SMS for the succeeding crop of button mushroom, the re-use of SMS will bring down the cost of cultivation along with saving of the environment and better processing of the SMS for other activities such as manure for field/horticultural crops. With this background, the present study was carried out to use the spent substrate obtained after $A$. bisporus cultivation in compost making for the next button mushroom crop and to study the nutritional composition of the compost such produced and the mushrooms grown on it.

\section{Materials and Methods}

\section{Compost formulations, compost making and cropping}

The compost was prepared with four different compost formulations using two phase short method of composting (Sinden and Hauser, 1950, 1953) during 2013-2015. In different compost formulations, SMS was used at three different proportions:- compost I - 20\% SMS (with N balancing), compost II - 20\% SMS (without $\mathrm{N}$ balancing) and compost III - 30\% SMS (without $\mathrm{N}$ balancing) weight/weight $(\mathrm{w} / \mathrm{w})$ in replacement of wheat straw on dry wt. basis, keeping standard compost formulation (wheat straw $1000 \mathrm{~kg}$, poultry manure $700 \mathrm{~kg}$, wheat bran $150 \mathrm{~kg}$, urea $15 \mathrm{~kg}$ and gypsum $35 \mathrm{~kg}$ ) being adopted at ICARDirectorate of Mushroom Research, Solan, India as the control check. SMS used was having $58-60 \%$ moisture at the time of experimentation, hence necessary corrections were made while deciding the quantity to be used. Gypsum was used at $35 \mathrm{~kg} /$ tonne of the basal material at third turning of phase-I of composting. The total Nitrogen at the beginning of composting was kept 1.60, 1.63 and $1.67 \%$ in standard formulation, compost-I, compost-II and compost-III, respectively by proportionate adjusting the quantities of poultry manure, wheat bran and urea. Finished compost or ready compost was spawned with 
Horst $\mathrm{U}_{3}$ hybrid at $0.7 \%$, w/w of the fresh compost and incubated at $23 \pm 2^{\circ} \mathrm{C}$ for spawn run. Finished compost here means compost which is ready for spawning and no further fermentation process is in place. One hundred twenty bags (1.2 tonne) of $10 \mathrm{~kg}$ compost each were kept for each treatment. The mycelial colonized compost bags were cased with farm yard manure (FYM) + Coir pith $(1: 1$, v/v) based steam pasteurized casing material. It was allowed for case run for another 8 days at $23 \pm 2^{\circ} \mathrm{C}$.

The cropping was done as per the standard cultural practices being followed at ICARDMR, Solan, India (Ahlawat and Manikandan, 2014). Fruiting body yield data was recorded in $\mathrm{kg}$ of freshly harvested fruiting bodies/q fresh compost for all the three cultivation trials conducted during 2013-15. Yield was recorded for one month of cropping starting from the first day of harvest.

\section{Compost analysis}

The samples of composts prepared with four different formulations of trial I were drawn at the time of spawning by following the standard protocol of compost sampling (Sharma, 2003). The samples were dried at $55-60{ }^{\circ} \mathrm{C}$ in a hot air oven, grind and sent for analysis. The samples were analysed for total organic carbon, organic matter, total Kjeldahl nitrogen, phosphorus, potassium and carbon: nitrogen ratio from Punjab Biotechnology Incubator, Mohali, India (a NABL accredited Agriculture and Food Testing Laboratory, Govt. of Punjab, India) as per the Govt. of India, The Fertilizer (control) Order, 1985 (1985).

\section{Fruit body analysis}

The harvested fruiting bodies from each compost composition of trial-I were analysed for their nutritional profiles. Nutritional profile means a profile covering important nutritional attributes of fruiting bodies. The randomly drawn 15-20 fruit bodies from each compost composition were analyzed for 14 different parameters viz., protein, carbohydrates, crude fibre, fat, ash, vitamin-D and 8 different minerals (calcium, sodium, potassium, iron, zinc, copper, magnesium and selenium) from Punjab Biotechnology Incubator, Mohali, India (a NABL accredited Agriculture and Food Testing Laboratory, Govt. of Punjab, India).

Standard procedures of AOAC were used for the determination of protein, carbohydrates, crude fibre, fat and ash content (AOAC, 2000). The protein content was determined first by determination of nitrogen percentage using Micro-Kjeldahl method, followed by its multiplication with a factor of 6.25. The percentage of crude protein, crude fat, minerals and ash were combined and subtracted from 100 to obtain the total carbohydrate percentage for each sample. Mineral constituents (iron, copper, zinc, selenium and magnesium) were determined by using ICP-MS method 999.10 (AOAC, 2000), while sodium and potassium by using flame photometer. Calcium was determined by Titrimetric Macro method, 910.01 (AOAC, 2000). Vitamin $D$ as Vitamin $D_{3}$ was determined using HPLC as per the protocol standardized at PBTI, Mohali. It was determined at a wavelength of $266 \mathrm{~mm}$ by using Eclipse XCB-C18 column, DAD (UVVIS) detector and Methanol/ Acetonitrile/ Water as the mobile phase. From $10 \mathrm{~g}$ mushroom sample, saponofied extract was prepared and out of it $1 / 10^{\text {th }}$ extract was loaded on silica gel column, followed by elution with n-heptane, drying and reconstitution using n-hexane/isopropanol. The reconstituted sample was run on HPLC along with requisite standard. 


\section{Statistics}

There were 12 replications for each treatment and the yield data was subjected to statistical analysis by single factorial ANOVA using OPSTAT (Sheoran et al., 1998).

\section{Results and Discussion}

\section{Compost output and quality attributes}

The conversion of wheat straw to ready compost was highest of 4.35 folds in $30 \%$ wheat straw substitution with SMS without $\mathrm{N}$ balancing treatment, followed by 3.59 folds conversion in $20 \%$ SMS without $\mathrm{N}$ balancing and lowest of 3.04 folds in control (standard formulation). It was almost at par (3.54 and 3.59 folds) in $20 \%$ SMS with and without $\mathrm{N}$ balancing treatments. The conversion was calculated using only the wheat straw used in compost composition and not the total ingredients as SMS is considered as worthless. The cost incurred in INR towards the inputs for production of 1 tonne of finished compost varied from highest of Rs. 3131 in case of control to lowest of Rs. 2210 in case of 30\% wheat straw replaced with SMS treatment. It was Rs. 2586 and Rs. 2667 in $20 \%$ SMS with and without $\mathrm{N}$ balancing treatments, respectively. The net saving (INR) in term of raw materials saved/tonne of finished compost was highest of Rs 921 in 30\% SMS substitution treatment, followed by Rs. 545 and Rs. 464 in $20 \%$ SMS with and without N balancing treatments, respectively.

The composts prepared with different proportions of SMS in place of wheat straw in trial-I varied in their quality characteristics. The values for total organic carbon and organic matter decreased with increasing quantity of SMS in place of wheat straw. The contents of nitrogen, phosphorus, potassium, total sugars, cellulose and lignin were higher in 20 and 30\% wheat straw replaced with SMS treatments without nitrogen balancing compared with other treatments including control. The carbon: nitrogen ratio was lower in these treatments (Table 1).

Mushroom growers are continuously looking for the ways to reduce the cost of production in A. bisporus. In A. bisporus production, compost alone accounts for around 50\% of the cost of production (Van Roestel, 1988) and in that, wheat straw is the major cost intensive ingredient (Jordan et al., 2008), which also is an important animal fodder. A. bisporus cultivation also generates huge quantity of the spent mushroom compost. The ratio of fresh mushrooms to SMS in button mushroom is around 1: 5 (Williams et al., 2001). This study focused on re-use of SMS obtained after growing A. bisporus as one of the compost ingredients in replacement of wheat straw and to assess its effect to compost output, quality parameters, yield and the nutritional attributes of the fruit bodies.

In present study, the compost output from one tonne of wheat straw was highest where 30\% of the wheat straw was replaced with $A$. bisporus SMS, followed by $20 \%$ wheat straw replacement with SMS. The higher compost output in SMS added treatments is attributed to the additional level of organic residue added in composting mixture in the form of SMS, which actually was not accounted during conversion as mushroom growers do not give monetary value to the SMS. In addition to this, the use of SMS also led to the monetary savings to the tune of INR 921 to $464 /$ tonne of the finished compost output or INR 2.32 to $4.60 / \mathrm{kg}$ fresh mushrooms. The finding is an important contribution to the scanty information on this aspect as only Royse (2012) has studied the effect of button mushroom SMS addition on the mushroom yield and the biological efficiency (BE). The composts produced from the treatments with SMS addition (at 20 and $30 \%$ without $\mathrm{N}$ 
balancing) also showed higher values of the total nitrogen, phosphorus and potassium compared to the compost from standard formulation. Here it is attributed to the increased level of nutritionally rich predecomposed agro-residue (SMS) in these composts, which helped in higher release and accumulation of these compounds in finished compost. Opposite of this, the values for total organic carbon, organic matter and Carbon: Nitrogen ratio was lower in compost with 20 and $30 \%$ SMS without nitrogen balancing compared with standard formulation. It is obvious as the SMS added was predecomposed, containing quite less quantity of the total organic carbon leading to lesser values of all these in finished compost. During mushroom cultivation process, the growing mushroom mycelia use more of carbon than nitrogen, hence the SMS has higher nitrogen percentage at the end of cropping. The major proportion of carbon left in SMS is in recalcitrant form and difficult to extract during re-composting process, hence the finished compost prepared with 20 and $30 \%$ SMS without $\mathrm{N}$ balancing (having higher proportion of poultry manure) was recorded to have lower values of organic carbon, organic matter and $\mathrm{C}: \mathrm{N}$ ratio. Contrary to this the higher Nitrogen level in SMS and its release during re-composting process may have contributed to the higher Nitrogen level in finished compost prepared from 20 and $30 \%$ SMS without $\mathrm{N}$ balancing (Fig. 1).

\section{Fruit body yield}

In three consecutive cultivation trials conducted during 2013-15, the fruit body yield varied between treatments as well as cultivation trials. It was significantly at par in four different composts in trial I. In trial II, it was highest in compost prepared with $20 \%$ wheat straw replaced with SMS and balancing of nitrogen. In rest two treatments, the fruit body yield was less than the standard control. In trial III, the fruit body yield was higher in all three SMS amended treatments compared with compost from standard formulation (Table 2). In all trials, the mean fruit body wt. was highest in treatment with $20 \%$ wheat straw replaced with SMS along with $\mathrm{N}$ balancing and lowest in control.

In majority of the earlier studies, the emphasis has remained on the use of A. bisporus SMS in A. bisporus compost preparation (Royse, 2012) or in double cropping after fragmentation of the compost, supplementation and addition of II phase compost@15\% (Royse, 2010; Royse and Chalupa, 2009). In first case, the use of $A$. bisporus SMS in compost making has been found to enhance the mushroom yield compared to compost from standard formulation (Royse, 2012). In this study, it has not been made clear whether the SMS was added as an additive or as replacement of wheat straw. Further the addition of SMS has been advocated at the beginning of the composting process instead at tunnel filling stage. No specific explanation has been offered for the enhanced level of mushroom yield on addition of SMS in the composting mixture. However, it may be due structural and nutritional changes in the compost. In the second case, where the fresh compost was added after $1^{\text {st }}$ flush break, it has been found to enhance the effect of other supplements towards enhancing the mushroom yield (Williams et al., 2001; Royse and Chalupa, 2009). Contrary to this, in present study the composts prepared with the addition of $A$. bisporus SMS at 20 and $30 \% \mathrm{w} / \mathrm{w}$ in replacement of wheat straw have been found to give either same level (trial I) or higher fruit body yield (trial III) compared to standard compost (Fig. 2). 
Table.1 Quality characteristics of the button mushroom compost prepared with different proportions of wheat straw replacement with button mushroom spent substrate

\begin{tabular}{|c|c|c|c|c|c|c|c|c|c|}
\hline SMS treatments & \multicolumn{7}{|c|}{ Button mushroom compost properties } \\
\hline & $\begin{array}{c}\text { TOC } \\
(\%)\end{array}$ & $\begin{array}{c}\text { OM } \\
(\%)\end{array}$ & $\begin{array}{c}\text { TKN } \\
(\%)\end{array}$ & $\begin{array}{c}\text { Phosphoru } \\
\mathrm{s}(\%)\end{array}$ & $\begin{array}{c}\text { Potassium } \\
(\%)\end{array}$ & C:N & $\begin{array}{c}\text { Total sugars } \\
\left(\mu \mathrm{gm}^{-1}\right)\end{array}$ & $\begin{array}{c}\text { Cellulose } \\
(\%)\end{array}$ & $\begin{array}{c}\text { Lignin } \\
(\%)\end{array}$ \\
\hline $\begin{array}{c}\text { Standard } \\
\text { formulation }\end{array}$ & 37.3 & 64.2 & 1.9 & 1.81 & 4.36 & 20 & 24.2 & 24.8 & 37.2 \\
\hline Compost - I & 37.4 & 64.4 & 1.9 & 1.82 & 4.28 & 20 & 30.0 & 24.6 & 44.4 \\
\hline Compost - II & 36.8 & 63.4 & 2.18 & 1.88 & 4.45 & 17 & 34.4 & 26.4 & 46.2 \\
\hline Compost - III & 36.7 & 63.2 & 2.17 & 1.98 & 4.68 & 17 & 34.4 & 25.6 & 46.4 \\
\hline SMS & 38.8 & 67.0 & 1.91 & 1.14 & 5.79 & 20 & n.d. & n.d. & n.d. \\
\hline
\end{tabular}

SMS - Spent mushroom substrate, TOC - Total organic carbon, OM - Organic matter, TKN - Total Kjeldahl

Nitrogen, C: N - Carbon/Nitrogen, n.d. - No data

Table.2 Fruit body yield in compost prepared with different proportions of wheat straw replaced with button mushroom SMS

\begin{tabular}{|c|c|c|c|c|c|c|c|c|c|}
\hline $\begin{array}{c}\text { Compost } \\
\text { treatments }\end{array}$ & \multicolumn{3}{|c|}{$\begin{array}{c}\text { Fruit body yield } \\
\text { compost) }\end{array}$} & \multicolumn{3}{c|}{$\begin{array}{c}\text { Nos. of fruit bodies } \mathbf{q}^{-1} \\
\text { compost }\end{array}$} & \multicolumn{3}{c|}{ Mean fruit body wt. (g) } \\
\hline & Trial I & Trial II & Trial III & Trial I & Trial II & Trial III & Trial I & Trial II & Trial III \\
\hline Compost-I & 16.93 & 13.93 & 13.05 & 1101 & 830 & 791 & 12.65 & 16.78 & 16.50 \\
\hline Compost-II & 16.10 & 11.09 & 13.24 & 1368 & 772 & 812 & 11.77 & 14.37 & 16.30 \\
\hline Compost-III & 16.27 & 10.51 & 12.77 & 1364 & 749 & 803 & 11.93 & 14.01 & 15.91 \\
\hline Control & 16.82 & 13.09 & 11.36 & 1431 & 832 & 738 & 11.75 & 15.72 & 15.40 \\
\hline CD $_{0.05}$ & 1.46 & 1.82 & 1.67 & 87.52 & 53.61 & 58.04 & 1.78 & 2.03 & 1.94 \\
\hline
\end{tabular}

SMS - Spent mushroom substrate, CD - Critical difference

Table.3 Quality characteristics of the fruit bodies harvested from compost prepared with different proportions of wheat straw replacement with button mushroom spent substrate

\begin{tabular}{|c|c|c|c|c|c|c|c|c|}
\hline \multirow[t]{3}{*}{ Parameters } & \multicolumn{8}{|c|}{ Different compost formulations } \\
\hline & \multicolumn{2}{|c|}{$\begin{array}{c}\text { Standard } \\
\text { formulation }\end{array}$} & \multicolumn{2}{|c|}{ Compost - I } & \multicolumn{2}{|c|}{ Compost - II } & \multicolumn{2}{|c|}{ Compost - III } \\
\hline & Flush-I & Flush-II & Flush-I & Flush-II & Flush-I & Flush-II & Flush-I & Flush-II \\
\hline Protein (\%) & 40.71 & 36.57 & 33.80 & 39.52 & 39.15 & 44.19 & 31.68 & 41.68 \\
\hline Crude fibre (\%) & 2.07 & 1.81 & 0.80 & 1.41 & 1.69 & 1.18 & 1.01 & 1.69 \\
\hline $\operatorname{Ash}(\%)$ & 10.23 & 11.05 & 10.35 & 11.44 & 11.20 & 11.47 & 9.98 & 11.83 \\
\hline Vitamin D ( $\mu \mathrm{g}$ g-100) & 231.9 & 678 & 612.6 & 737.8 & 241.8 & 632.7 & 340.6 & 1285.7 \\
\hline Potassium (\%) & 4.47 & 5.25 & 4.76 & 5.50 & 5.10 & 5.39 & 4.65 & 5.68 \\
\hline Potassium: Sodium & 88.87 & 71.82 & 89.64 & 83.59 & 91.23 & 80.33 & 82.45 & 82.80 \\
\hline Iron (mg kg-1) & 98 & 89 & 104 & 98 & 107 & 179 & 132 & 173 \\
\hline Manganese (mg kg $\left.{ }^{-1}\right)$ & 8.45 & 7.44 & 7.60 & 9.07 & 8.72 & 9.81 & 9.73 & 10.28 \\
\hline Zinc (mg kg $\left.{ }^{-1}\right)$ & 61 & 52.6 & 53.8 & 60 & 79.2 & 64.6 & 60.2 & 66.2 \\
\hline Selenium $\left(\mathrm{mg} \mathrm{kg}^{-1}\right)$ & 2.45 & 3.60 & 2.17 & 4.22 & 2.24 & 5.51 & 2.04 & 5.39 \\
\hline Copper (mg kg $\left.{ }^{-1}\right)$ & 37.1 & 34.7 & 34.2 & 36.5 & 45.1 & 46.1 & 34.7 & 46.0 \\
\hline
\end{tabular}


Fig.2 Button mushroom crop on compost prepared with wheat straw replacement with button mushroom spent substrate

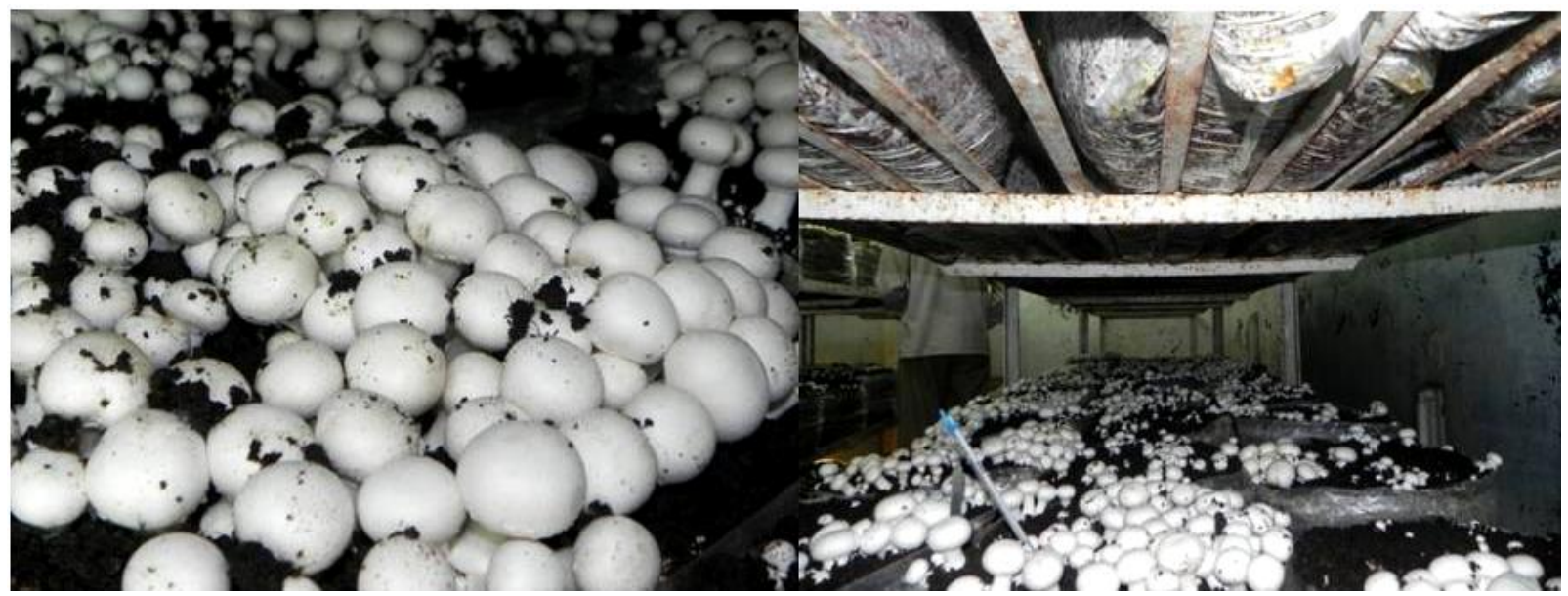

In either case, the saving of raw ingredients to the tune of INR 464 to $921 /$ tonne of finished compost leading to the savings of INR 3.0 lakh/year or 5,000 US\$/year for the mushroom unit of 100 tonne fresh mushroom/year and INR 30.0 lakh or 50,000 US\$ for mushroom unit of 1000 tonne fresh mushroom/year capacities, is a worth saving besides proper management of the SMS and saving of the environment.

The use of SMS in compost making to grow A. bisporus will also have several other benefits like reduction in the volume of compost ingredients needed - a substantial economic benefit, reduction in the volume of spent mushroom compost left to find beneficial reuse, and improvement in the quality of spent mushroom compost for further processing as manure.

\section{Nutritional attributes of fruiting bodies}

The nutritional profile of the fruiting bodies from different composts showed variation in majority of the parameters. Protein in $1^{\text {st }}$ flush was highest in control treatment while in $2^{\text {nd }}$ flush it was significantly higher in SMS added compost treatments. The crude fibre content was higher during both the flushes in control treatment compared with SMS substituted treatments. It was followed by the compost with 20\% SMS without $\mathrm{N}$ balancing. The other constituents like ash, minerals (potassium, iron, manganese, zinc, selenium and copper), potassium/sodium ratio and vitamin $\mathrm{D}$ were also higher in fruit bodies harvested from the composts prepared with substitution of wheat straw with different quantities of SMS. For majority of the parameters, the fruit bodies from the compost with $20 \%$ SMS without $\mathrm{N}$ balancing showed higher values compared with fruit bodies from other compost treatments (Table 3).

The positive changes in the nutritional profiles of the fruiting bodies harvested from the composts prepared with SMS in place of wheat straw are an additional benefit. For majority of the parameters like ash, vitamin D and minerals, the fruiting bodies from composts with added SMS were superior. It can be attributed to superior nutritional status of the composts prepared with the addition of A. bisporus SMS in place of wheat straw. Studies of this nature are quite scanty in which the fruiting bodies harvested from different types of composts have been compared for their nutritional profiles. In one such study, the $A$. bisporus fruiting bodies from the 
organically prepared compost were superior in their nutritional profiles compared with the fruit bodies from standard compost (Dhar et al., 2004). The superior nutritional profile of the fruiting bodies was attributed to the nutritional superiority of the compost prepared organically. In case of $30 \%$ wheat straw substitution with SMS there was no increase in protein content of the fruiting bodies. In this case as the proportion of SMS was enhanced to $30 \%$, the quantity of other nutritional components like wheat bran and urea was reduced keeping in same proportion against wheat as in case of standard formulation. It might have restricted the availability of precursors required for protein synthesis in fruiting bodies. There are good chances of getting a pathogens infected SMS and recycling of which might pose a threat to the succeeding button mushroom crop. Here the check is our two phase method of compost production, which undergoes succession of different environmental conditions of extreme temperature, $\mathrm{pH}$ and microbial population. There are minimal chances of survival of the pathogens contributed by the SMS, if all steps of compost making are followed judiciously.

The replacement of wheat straw with $20 \%$ SMS along with balancing of nitrogen by reducing the quantity of poultry manure added to the compounding mixture, gave numerically higher fruit body yield in first two yield evaluation trials. It also resulted in saving of the cost of compost production as $30 \%$ lesser quantity of poultry manure was used compared to $20 \%$ SMS composition compost without $\mathrm{N}$ balancing. The only bottleneck recorded with this treatment was lesser protein content in fruiting bodies compared to other compost treatments. The other nutritional parameters like ash, potassium, iron, potassium: sodium ratio and vitamin-D content were also in favour of compost prepared with SMS compared to standard formulation.

\section{Acknowledgements}

The authors express their thanks to Ms. Bindvi Arora, Scientist, ICAR-DMR, Solan, India for helping in analysis of the compost and the Director, ICAR-DMR, Solan, India for providing the requisite facility for the aforesaid research programme.

\section{References}

A.O.A.C., (2002). Official Methods of Analysis of AOAC International, $17^{\text {th }}$ ed., $1^{\text {st }}$ revision, Gaithersburg, $\mathrm{MD}$, USA, Association of Official Analytical Chemists.

Ahlawat, O.P., and Manikandan, K. 2014. Effect of compost compression, perforation in compost bags and watering schedule on yield of white button mushroom, Agaricus bisporus. Mushroom Res. 23: 145-151.

Beyer, M. 1996. The impact of the mushroom industry on the environment. Mushroom News. 44(11):6-13.

Dhar, B.L., Ahlawat, O.P., Dubay, J.K. and Nath, A. 2004. Organic mushroom production in India, technology and residue assay. Mushroom Sci. XVI: 289-295.

Fertilizer (Control) Order. 1985. Biofertilizers and Organic Fertilizers in Fertilizer (Control) Order, 1985. National Centre of Organic Farming, DoAC, Ministry of Agriculture, Govt. of India, CGO-II, Kamla Nehru Nagar, Ghaziabad, 201001, Uttar Pradesh (ncof.dacnet.nic.in/Training_manuals/ Training_manuals.../BF_and_OF_in_F CO. pdf), accessed on 12/04/2019.

Fidanza, M.A. and Beyer, D. 2009. Plant nutrients and fresh mushroom compost. Mushroom News. 57: 4-9.

Jordan, S.N., Mullen, G.J. and Murphy, M.C. 2008. Composition variability of spent 
mushroom compost in Ireland. Bioresour. Technol. 99: 411-418.

Kilpatrick, M., Murray, D.J. and Ward F. 2000. Influence of substrate formulation and autoclave treatment on Lentinula edodes production. Mushroom Sci. 15: 803-810.

Mueller, J.C., Gawley, J.R. and Hayes, W.A. 1984. Utilization of spent alder compost as a substrate for cultivation of Pleurotus sajor-caju. Mushroom Newsletter Tropics. 5(2): 3-7.

Phan, C.W. and Sabaratnam, V. 2012. Potential uses of spent mushroom substrate and its associated lignocellulosic enzymes. Appl. Microbiol. Biotechnol. 96: 863-873.

Poppe, J. 2000. Use of agricultural waste materials in the cultivation of mushrooms. Mushroom Sci. 15: 3-22.

Royse, D.J. Effects of fragmentation, supplementation and the addition of phase II compost to 2nd break compost on mushroom (Agaricus bisporus) yield. Bioresour. Technol.101: 188192.

Royse, D.J. 2012. Use of spent mushroom substrate (SMS) as an ingredient in mushroom compost formulation. Mushroom Sci. 18: 709-713.

Royse, D.J. 2014. A global perspective on the high five: Agaricus, Pleurotus, Lentinula, Auricularia and Flammulina. In: Proceedings of $8^{\text {th }}$ International Conference on Mushroom Biology and Mushroom Products (Eds.) M. Singh, R.C. Upadhyay, V.P. Sharma, O.P. Ahlawat, S. Kumar, S. Kamal, B. Arora and M. Gupta. WSMBMP, MSI \& DMR, Solan, India, pp. 1-6.

Royse, D.J. and Chalupa, W. 2009. Effects of spawn, supplement, and phase II compost additions and time of recasing second break compost on mushroom (Agaricus bisporus) yield and biological efficiency. Bioresour. Technol. 100: 5277-5282.

Sharma, H.S.S. 2003. Mushroom compost production, sampling and sample selection for development of NIR calibrations. In: Near Infrared Spectroscopy: The proceedings of the 11th NIR International Conference Cordoba, Spain (Eds.) A.M.C. Davis and A. Garrido-Varo. NIR publications, Chichester, pp. 327-332.

Sinden, J.W. and Hauser, E. 1950. The short method of composting. Mushroom Sci. 1: 52-59.

Sinden, J.W. and Hauser, E. 1953. The nature of the composting process and its relation to short composting. Mushroom Sci. 2: 123-131.

Singh, M. 2011. Mushroom production: an agribusiness activity. In: Mushrooms Cultivation, Marketing and Consumption (Eds.) M. Singh, B. Vijay, S. Kamal and G.C. Wakchaure. Directorate of Mushroom Research, Solan, India, pp. 1-10.

Sheoran, O.P., Tonk, D.S., Kaushik, L.S., Hasija, R.C. and Pannu, R.S. 1998. Statistical Software Package for Agricultural Research Workers. In: Recent Advances in information theory, Statistics \& Computer Applications (Eds.) D.S. Hooda and R.C. Hasija. Department of Mathematics and Statistics, CCS HAU, Hisar, pp. 139-143.

Van Griensven, L.J.L.D. 1988. The Cultivation of Mushrooms. Mushroom Experimental Station, Horst, The Netherlands.

Van Roestel, A.J.J. 1988. Costs and returns. In: The Cultivation of Mushrooms (Eds.) L.J.L.D. Van Griensven. Mushroom Experimental Station, Horst, The Netherlands, pp. 447-483.

Williams, B.C., McMullan, J.T. and McCahey, S. 2001. An initial 
assessment of spent mushroom compost as a potential energy feedstock. Bioresour. Technol.79: 227-230.
Wuest, P.J. 1983. Resources need to farm the "champignon". Mycologia.75: 341350 .

\section{How to cite this article:}

Om Parkash Ahlawat and Harleen Kaur. 2019. Re-use of Agaricus bisporus Spent Compost for Commercial Scale Compost Making of the Succeeding Crop of A. bisporus. Int.J.Curr.Microbiol.App.Sci. 8(11): 177-186. doi: https://doi.org/10.20546/ijcmas.2019.811.022 